\title{
The RELATIONSHIP BETWEen FOOD SOVEREIGNTY AND HAWAIIAN HEALTH: THE IMPLICATIONS BEHIND ALEXANDER AND BALDWIN's RECENT LAND SALE
}

\author{
KAYLEE KILOLANI MICHIKO CORREA
}

\section{INTRODUCTION}

The Hawaiian creation story, or Kumulipo, features Wākea (sky-father) and Papa (earth-mother), parents of the Hawaiian Islands. ${ }^{1}$ Ho' ohōkūlani was the daughter of Wākea and Papa; Wākea and Ho'ohōkūlani had a stillborn baby boy, so they buried him on the east side of their house, facing the sunrise. ${ }^{2}$ A plant soon grew in the burial spot, which became the first kalo (taro) plant, named Hāloanakalaukapalili. ${ }^{3}$ Wākea and Ho'ohōkūlani had another son, named Hāloa, to honor his older brother, Hāloanakalaukapalili; Hāloa is said to be the first Hawaiian and all Hawaiians trace their mo'oküauhau (genealogy) back to Hāloa ${ }^{4}$

This story illustrates the familial-like connection Hawaiians have with the land and the vitality of that connection:

Kānaka Maoli [Native Hawaiians] trace their ancestry to the 'āina (land),

to the natural forces of the world, and to kalo (taro), the staple food of the

Hawaiian people. All are related in a deep and profound way that infuses

Hawaiian thought and is expressed in all facets of Hawaiian life. ${ }^{5}$

Native Hawaiian ${ }^{6}$ land rights have been a highly debated issue for the past

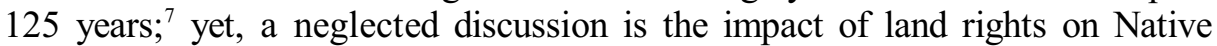
Hawaiian health. While obesity rates in Hawai'i have decreased significantly in the past seven years, Hawai $i$ still ranks 25 out of 50 for diabetes-related deaths, 17 out of 50 for physical inactivity, 29 out of 50 for low birthweight, and 38 out of 50 for excessive drinking, according to America's Health Rankings. ${ }^{8}$

1. Hāloa, KumuKAHI, http://www.kumukahi.org/units/ka_hikina/haloa [https://perma.cc/ NPE9-ZWBD]; Cosmology, HAw. HIS., http://www.hawaiihistory.org/index.cfm?fuseaction=ig. page\&CategoryID=276 [https://perma.cc/8FC5-SVVC].

2. Hāloa, supra note 1 .

3. $I d$.

4. $I d$.

5. Melody Kapilialoha MacKenzie, Historical Background, in Native Hawaiian Law: A Treatise 1, 6 (Melody Kapilialoha MacKenzie et al. eds., 2015).

6. For the sake of this Note, "Native Hawaiians" and "Hawaiians" are used interchangeably to denote all peoples of Hawaiian ancestry. See HAw. REV. StAT. § 10-2 (2018).

7. See Hawaii v. Office of Hawaiian Affairs, 556 U.S. 163, 163 (2009) (holding that after the Hawaiian monarchy was overthrown in 1893, Hawai'i ceded all of its land to the U.S., including "public, government, and crown lands," and that despite the 1993 congressional Apology Resolution, the State maintains the power to use or sell that land, as long as the "proceeds are held in trust for Hawaiian citizens").

8. United Health Found., Hawaii Summary 2017, America's Health Rankings, https://www.americashealthrankings.org/explore/annual/measure/Overall/state/HI?editionyear=2017 [https://perma.cc/Y594-S9QR]. The low birth weight ranking is significant because one 
These poor health statistics are a result of, amongst other factors, a postcolonization reliance on imported and processed foods. ${ }^{9}$ So, reliance on food produced on Hawai'i soil, particularly foods that fall within Traditional Hawaiian means of subsistence, seem to be a plausible solution to improving the health of our people. ${ }^{10}$ This concept is otherwise known as food sovereignty: ${ }^{11}$ A general definition of the concept is as follows:"[f]ood sovereignty . . . is that state of being in which 'all community residents obtain a safe, culturally acceptable, nutritionally adequate diet through a sustainable food system that maximizes community self-reliance and social justice." "12 However, it is difficult to pursue this endeavor when there is little land available; for instance, $\operatorname{taro}^{13}$ farmers in Hawai' $i$ face a handful of challenges, including a rapidly decreasing amount of agricultural land and a recent Maui land sale demonstrates the importance of food sovereignty.

The Alexander \& Baldwin Company (“A\&B") possessed over 41,000 acres of sugar cane land on Maui and retained land and water rights to all of it; however, A\&B stopped its sugar cane production in 2016 after 145 years of production..$^{14}$ In 2018, A\&B sold 41,000 acres of sugar cane land to a Californiaowned company called Mahi Pono. ${ }^{15}$ Initial reports suggest that Mahi Pono plans to grow a wide range of crops, such as coffee, fruits, and vegetables for local use and as exports. ${ }^{16}$ Mahi Pono also acquired Kūlōlio Ranch, A\&B's grass-fed cattle production project in partnership with Maui Cattle Company, and Central Maui Feedstocks. ${ }^{17}$ Mahi Pono's two land purchases makes them the biggest private

of the causes of low birth weight is mothers experiencing high blood pressure, diabetes, heart disease, or lung disease, all problems that can result from poor diets.

9. See Claire K. Hughes, Traditional Hawai ian Diet Programs: A Culturally Competent Chronic Disease Intervention, 5 PaC. Health Dialog 328 (1998).

10. See Kathryn True, Reclaiming Tradition: Native Hawaiian Health Systems Emphasize Healing Ties to the Land, In Context: Good Med. 54 (1994).

11. Alicia Bell-Sheeter, Food Sovereignty Assessment Tool 4 (2004). Food sovereignty also includes the right (for all people) to generate "culturally appropriate" food and the right to self-sustaining food resources.

12. Id.

13. Jeremy Miller, The (Poi) Power of Hawaiian Food Sovereignty, SIERRA CLUB (Mar. 8, 2017), https://www.sierraclub.org/sierra/2017-2-march-april/feature/poi-power-hawaiian-foodsovereignty [https://perma.cc/SS7L-QQUL]. Taro was and is an integral part of the Hawaiian diet; ancient Hawaiians would eat up to ten pounds of poi (pounded taro mixed with water) per day.

14. Lee Imada, A\&B Map Shows Possible Uses for Fallow Sugar Fields, MAUi News (Apr. 1, 2017), http://www.mauinews.com/news/local-news/2017/04/ab-map-shows-possible-uses-forfallow-sugar-fields/ [https://perma.cc/9C9M-24YE]. A\&B Sells 41,000 Acres of Former Maui Sugar Lands, HAwAII News Now (Dec. 20, 2018, 1:51PM), http://www.hawaiinewsnow.com/ 2018/12/20/ab-sells-acres-former-maui-sugar-lands/ [https://perma.cc/R6D8-XN34].

15. A\&B Sells 41,000 Acres of Former Maui Sugar Lands, supra, note 15.

16. $I d$.

17. Id. 
landowner on Maui. ${ }^{18}$

The people of Hawai' $i$ are quite familiar with private corporations coming in and purchasing land for commercial land development. ${ }^{19}$ Haunani-Kay Trask, a prominent Hawaiian activist, educator, and writer, noted that since 1893, Hawaiian lands have been used for things like urbanization, resorts, and plantation agriculture. ${ }^{20}$ While most Hawaiians are not supportive of the land development that occurred and continues to occur throughout the islands, they disagree on something that could impact Hawaiian land rights: federal recognition. ${ }^{21}$

Federal recognition is one of several Hawaiian rights advocacy approaches circling around the Native Hawaiian community ${ }^{22}$ - indigenous peoples rights, decolonization, and sovereignty are the three other main theories. ${ }^{23}$ Federal recognition grants tribes a government-to-government relationship with the United States in which they can self-govern and receive federal assistance. ${ }^{24}$ The indigenous peoples rights theory is rooted in international human law and focuses on protecting Native Hawaiian rights within the American legal structure. ${ }^{25}$ Decolonization is also rooted in international law and strives to turn the state into an independent nation-state. ${ }^{26}$ Lastly, sovereignty is based on the "States-rights frame of international law" and seeks to restore the Hawaiian monarchy. ${ }^{27}$

A modified model of federal recognition is the logical and most immediate resolution to Hawaiian health issues because it would be a major step towards Hawaiian food sovereignty. ${ }^{28}$ In order to understand this, Section II explains the history of Hawai' $i$, focusing on events leading up to and including the transformation in the land ownership and usage system from AD 600 until today. Section II will also provide an overview of Native Hawaiian health. Section III

18. Id.

19. Haunani-Kay Trask, The Struggle for Hawaiian Sovereignty - Introduction, CULTURAL Survival (Mar. 2000), https://www.culturalsurvival.org/publications/cultural-survivalquarterly/struggle-hawaiian-sovereignty-introduction [https://perma.cc/W9QU-6W64].

20. Id.

21. Anita Hofschneider, The Coming Debate on Federal Recognition for Native Hawaiians, Honolulu Civ. BeAt (June 23, 2014), https://www.civilbeat.org/2014/06/the-coming-debate-onfederal-recognition-for-native-hawaiians/ [https://perma.cc/6PNQ-MJQD].

22. Telephone Interview with Melody Kapilialoha Mackenzie, Law Professor, Univ. of Hawai'i i at Mānoa (Jan. 25, 2019) [hereinafter Interview].

23. S. James Anaya \& Robert A. Williams, JR., Study On The International Law And Policy Relating To The Situation Of The Native Hawailan People i, ii (2015), http:// legislature.maine.gov/doc/3139 [https://perma.cc/H43Q-6JXV].

24. Frequently Asked Questions, U.S. DEP'T InTERIOR: INDIAN AFFS., https://www.bia.gov/ frequently-asked-questions [https://perma.cc/95MA-92C6].

25. Anaya \& Williams, supra note 24 , at 3.

26. $I d$.

27. Id. at 19 .

28. See Bell-SheEter, supra note 11. 
will explore the concept of food sovereignty in general and how it can operate in Hawai'i. Section IV offers a case study of the multimillion-dollar sale of A\&B sugar cane land on Maui to a farming venture company, Mahi Pono. Section V discusses the different legal theories Hawaiian scholars have analyzed to reclaim Hawaiian land rights. Finally, Section VI proposes a federal regulation as the most immediately attainable opportunity for Hawaiians, specifically on Maui, to progress towards food sovereignty.

\section{THE LITTLE-KNOWN NARRATIVE OF "PARADISE"}

\section{A. Hawaiian History}

Hawai $i$ attracts millions of tourists every year: in 2017, nearly 9.3 million visitors ventured to Hawai ${ }^{2} .^{29}$ The tourism industry alone generates billions of dollars for our state. ${ }^{30}$ And though tourists visit the state to escape reality, it is important to remember the origin of "paradise" and the historical, spiritual link Hawaiians share with their land.

\section{Hawaiian Society Pre-Contact}

Though the date of the original settlement of the Hawaiian people is debated, the widely agreed upon timeframe is sometime in the 10th century, but no later than $\mathrm{AD} 1200 .{ }^{31}$ Most evidence comes from early settlers on $\mathrm{O}^{\prime} \mathrm{ahu}$, who were agriculturalists; from about AD 600-1100, the Hawaiian social system was communal and organized around subsisting the "ohana where people had equal control over the land and natural resources. ${ }^{32}$

Once the community grew on $\mathrm{O}^{6} \mathrm{ahu}$, chiefs implemented many "public works" projects, which eventually spread to the rest of the islands; these projects produced a great amount of food while simultaneously supporting the remodeled Hawaiian social system. ${ }^{33}$ Despite this new social classification system, the Kānaka Maoli remained an agriculture and family-based economy ${ }^{34}$ Ahupua 'as (land divisions running from the ocean to the mountains) were the most common forms of land units used by the Hawaiian people; commoners built irrigation systems, fishponds, hunted, harvested kalo, and fished. ${ }^{35}$ In other words, private

29. Katie Murar, Hawaii Tourism Industry Sets Record for Sixth Consecutive Year, PAC. Bus. NEws (Jan. 31, 2018, 3:50 PM), https://www.bizjournals.com/pacific/news/2018/01/31/hawaiitourism-industry-sets-records-for-sixth.html [https://perma.cc/E8L5-9MCZ].

30. Id. Tourist spending produced $\$ 1.96$ billion in state tax revenue.

31. MACKENZIE, supra note 5, at 6.

32. Id.

33. Id. at 7. On Hawai' $i$ Island, projects included $l o^{\circ} i$ (irrigated taro terraces), water irrigation systems, and heiau (places of worship); on Moloka'i and $\mathrm{O}^{\prime}$ ahu, large fishponds were implemented. The "new" social classes were the ali $i$ (chiefs), kahuna (priests), and maka'äinana (commoners).

34. Id.

35. Id. at 9. "Maka"äinana could freely trade and move within the ahupua'a. . . these activities were regulated by an intricate system of rules designed to conserve natural resources and 
land ownership did not have a place in Ancient Hawai' $i$ and was introduced when Westerners arrived. ${ }^{36}$ Thus, the Hawaiians' "mutual dependence" lifestyle worked well for centuries prior to the arrival of Captain Cook.

\section{Colonizers Arrive - Land Use and Ownership Transforms}

Captain James Cook was an English navigator who "discovered" places such as Tahiti, New Zealand, and Australia. ${ }^{37} \mathrm{He}$ landed on $\mathrm{O}^{6}$ ahu in 1778, where he was welcomed as a high chief or god. ${ }^{38}$ Upon Cook's arrival, the estimated Hawaiian population was between 400,000 to one million. ${ }^{39}$ The land ownership system was stable and spanned across all eight islands by this time. ${ }^{40}$ After Kamehameha united all the islands, he delegated governance over lands to his chiefs in the traditional Hawaiian manner and appointed other loyal ali $i$ (chiefs) as governors over each island. ${ }^{41}$

Kamehameha I began to trade land with Westerners in exchange for services, and soon, Westerners wanted the right to grant land to their heirs. ${ }^{42}$ Land rights between natives and foreigners immediately became an issue. ${ }^{43}$ For instance, the 1840 Hawai' $i$ Constitution maintained the traditional land system, but created limitations, and was interpreted to prohibit the king from reclaiming land held by foreigners and allowing 50-year leases between governors and foreigners. ${ }^{44}$ Westerners pressured the Hawaiian government to secure their land, sometimes utilizing the influence of Hawaiian government allies and foreign gunboats. ${ }^{45}$ Several years later, the Māhele occurred, which was a process of multiple land divisions; the lands were split into Government Lands, the King's Lands, the ali ${ }^{i} i$ and konohiki (headman of the ahupua' $a$ ) lands, and kuleana lands. ${ }^{46}$

provide for all ahupua 'a residents."

36. Id.

37. Cook, James (1728-1779), Austrl. DiCTIONARy Biography, http://adb.anu.edu.au/ biography/cook-james-1917 [https://perma.cc/5AX5-HK66]. "Discovered" is in quotations to reference the Doctrine of Discovery, or the justification used by colonial powers to claim title to lands that were "newly discovered" by "invalidating or ignoring aboriginal possession;" this doctrine is still used in American Indian law. What is the Doctrine of Discovery?, Doctrine DISCOVERY, https://doctrineofdiscovery.org/what-is-the-doctrine-of-discovery/ [https://perma.cc/ JM8J-BKZS].

38. Captain Cook Arrives in Hawai i, HAwAIHISTORY.org, http://www.hawaiihistory.org/ index.cfm?fuseaction=ig.page\&PageID=265 [https://perma.cc/T335-ZB5R].

39. MACKENZIE, supra note 5 , at 48.

40. See id. at 11.

41. Id. at 10 .

42. Id.

43. See $i d$. at 11 .

44. Id. at 11,12 .

45. Id.

46. Id. at 14 . 
Five years after the Māhele, the maka'äinana were to receive about one-third of the total land in Hawai' $i$, but, they were only awarded about $1 \%$ via the Kuleana Act of $1850 .{ }^{47}$ At this point, land rights steadily began to slip out of Hawaiian control and into Western hands. ${ }^{48}$ Essentially, Westerners manipulated the Hawaiian economy to benefit themselves by exploiting Hawai' $i$ sandalwood and introducing large-scale sugar plantations. ${ }^{49}$ Many kuleana land grants were lost in this economic shift because natives were not taught this foreign legal system; additionally, the kuleana lands became wedged in between big agricultural or ranching ahupua $a$ that were now Western-owned. ${ }^{50}$

Moreover, the Kuleana Act contained a "really cultivated" clause that, upon court interpretation, prohibited farmers from claiming land; because Hawaiians had always utilized the ahириа' $a$ communally, there were only a small number of individual farmers. ${ }^{51}$ Further, Oni v. Meek, 2 Haw. 87 (1858) found that the Kuleana Act did not allow for the maka'ainana to grow crops or animals on unclaimed parts of an аһириа' $a$ because the Act only included land that the farmer cultivated and a lot for their home not exceeding a quarter acre. ${ }^{52}$

Some believe Westerners illegally seized land from Hawaiians during this time, but it can be argued that the land transfers were a choice made by the kings and chiefs..$^{53}$ In essence, they chose to accept the Western land ownership system because they were not only pressured to do so, but because they wanted to ensure the survival of their people. ${ }^{54}$ Nevertheless, the maka a ainana attempted to band together and hold these lands communally, but due to the fractioning of land interests, particularly sales to plantations, Hawaiians lost even more land. ${ }^{55}$ Similarly, chiefs lost control of their lands through debts owed to Westerners. ${ }^{56}$

47. Act of Aug. 6, 1850, Granting to the Common People Allodial Titles for Their Own Lands and House Lots, and Certain Other Privileges [hereinafter Kuleana Act], reprinted in PENAL CODE OF THE HAWAIIAN ISLANDS 32-33 (1850), http://punawaiola.org/es6/index.html?path=/ Collections/Statutes/PenalCode1850001.pdf [https://perma.cc/J5SE-YDJ8]. MACKENZIE, supra note 5 , at 15 .

48. Neil M. Levy, Native Hawaiian Land Rights, 63 CAL. L. Rev. 848, 857 (1975).

49. Id. at 857. Levy also notes that, due to the importation of foreign labor for Asia and Europe, Hawaiians soon became "a minority in their own homeland."

50. MACKENZIE, supra note 5, at 17. Because native kuleana land farmers could not access former common cultivation and livestock areas, they were forced to leave their lands, which were either absorbed by surrounding landowners via adverse possession or simply not returned to them after being leased to Westerners.

51. See id. at 15. Other reasons why Hawaiians could not secure kuleana land include: they could not afford it, they were unaware of or did not understand Western land laws, they did not want to betray their chiefs by claiming land, and the population of Hawaiians severely decreased due to widespread epidemics.

52. Id. at 15-16.

53. Interview, supra note 23.

54. See MACKenZIE, supra note 5, at 16-17.

55. Id.

56. Id. Chiefs who tried to start large-scale agriculture were unable to meet the monetary 
Government Lands were sold to native tenants in this post Māhele era to ensure that the Kuleana Act was upheld. ${ }^{57}$ But, by this time, Westerners possessed about 320,000 acres of Government Lands. ${ }^{58}$ This land transition marked the beginning of the descent of the Hawaiian kingdom and culture.

\section{The Overthrow and Its Results}

King David Kalākaua was forced to sign the 1887 Constitution ("Bayonet Constitution") due to the demands of "Western business interests," even though he intended to abolish voter property qualifications from the Constitution of $1864 .{ }^{59}$ In 1893, Queen Lili ${ }^{6}$ uokalani drafted and was set to authorize a new constitution, but the U.S. minister to Hawai' $i$, John Stevens, ordered American marines to Honolulu to "protect American lives and property" on January 16, $1893 .{ }^{60}$

By this point, the rise of plantation-style agriculture meant most of the Government Lands were owned by non-Hawaiians; many sugar plantations had long-term leases on Government and Crown Lands. ${ }^{61}$ The Provisional Government took control of Government Lands and the Crown Lands and, when annexation with the United States failed, formed the Republic of Hawaii in $1894 .^{62}$ The Republic passed the 1895 Land Act, which merged the Crown and Government lands into public lands. ${ }^{63}$ In 1895 , after royalist groups battled with the Republic and martial law was declared, the royalist groups and Lili'uokalani herself were arrested and she formally renounced the throne to the United

demands of maintaining plantations and lost their land through foreclosure.

57. Id. at 18 .

58. Id.

59. Id. at 19-20. Kalākaua's powers were reduced significantly - his military powers were subject to legislative control and his status became more symbolic than anything. See HAwAII, Laws of Her Majesty Liliuokalani, Queen of the Hawailan Islands: Passed by the LEgislative ASSEMBly AT ITS SESSION, 1892 343, 355 (1892), https://babel.hathitrust.org/ cgi/pt?id=mdp. $35112204552212 \&$ view $=1$ up\&seq $=9$.

60. See MAcKenzIE, supra note 5, at 20-21. American and European businessmen who controlled the Hawaiian economy formed a "committee of safety" and proposed annexation to the U.S. by using the sugar industry as its primary motivation. Annexationists then seized the government building, proclaimed that the monarchy was no more, and a Provisional Government was now in place. Queen Lili'uokalani realized that resisting could result in the unnecessary bloodshed of her people, so she ceded her power to the United States.

61. See id. at 18. The last census before the Overthrow, taken in 1890, showed that Hawaiians owned very little land, if any; though a small population, Westerners owned over a million acres of land.

62. MACKENZIE, supra note 5, at 24-25.

63. Id. at 24-25. "139 Americans received 10,084 acres . . . in contrast, 230 Hawaiians received 6,502 acres.” 
States. ${ }^{64}$

\section{Annexation, Statehood, and Beyond}

Eventually, the United States annexed the Republic of Hawai' $i$ and the Republic ceded title to all public lands to the U.S. ${ }^{65}$ The estimated amount of land was about 1.8 million acres and valued around $\$ 5.5$ million. ${ }^{66}$ The 1900 Organic Act stated that all ceded public lands would remain in control of the government and any sale or lease revenue coming from those lands would be deposited into the Territory of Hawai'i's treasury to "benefit . . . inhabitants of the Territory of Hawai' i." ${ }^{\circ 67}$

By 1921, the Hawaiian Homes Commission Act ("HHCA") was enacted, making over 200,000 acres of public land available to be leased for homesteading $^{68}$ for Native Hawaiians with at least $50 \%$ of Native Hawaiian blood. ${ }^{69}$ And yet, the HHCA still protected the interests of sugar plantation owners because "cultivated sugarcane lands," under "homestead lease[s]," lands under right of purchase leases, and lands under "certificate[s] of occupation" were excluded from the Act. $^{70}$

In the 1959 Hawai' $i$ Admissions Act, the federal government turned over title to the majority of the "public lands" to the new state; additionally, the Act required the state to adopt the HHCA. ${ }^{71}$ Approximately 373,719 acres of the public lands were set aside for federal government and military use. ${ }^{72}$ The lands

64. See id. at 25. In fear of her supporters' deaths, the Queen officially renounced all claims to the throne.

65. See id. at 27.

66. See id. at 27, 79. The ceded lands were Hawaiian Government and Crown Lands, originally reserved for Hawaiians despite the transition to the "fee-simple ownership system" resulting from the Māhele. According to Professor MacKenzie, the Joint Resolution of Annexation (enacted in 1898 by Congress) "implicitly recognized the trust nature of the Government and Crown Lands," yet, much of the land was used by the federal government. Thus, the "ceded" lands are often referred to as "public land trust" or "trust lands."

67. Id. at 28. The Act was enacted, at least in part, to benefit of Hawai' 1 inhabitants, however, the U.S. had legal title to the lands, thus, the federal government retained the right to use land.

68. Homesteading, Merriam-Webster Dictionary (2019). "Homesteading” can be defined as: "the home and adjoining land occupied by a family" or "a tract of land acquired from U.S. public lands by filing a record and living on and cultivating the tract."

69. MACKENZIE, supra note 5, at 30-31. Hawaiian leaders originally asked for a bill that would allow Hawaiians without any amount of "aboriginal blood" to be eligible for these homestead lands, but sugar plantation owners made it so that the blood quantum was set at $50 \%$ to protect their land interests.

70. Id. at 31 .

71. Id. at 33 .

72. See id. at 32. 227,972.62 acres of land were national parks. The federal government also had permits and licenses for another 117,413 acres of land and had acquired the fee interest of 28,235 acres. 
that the new state received were to be held in trust for one of more of five trust purposes including "the betterment of the conditions of native Hawaiians, as defined in the [HHCA]." ${ }^{" 73}$ The 1978 Hawai' $i$ Constitution stated that the Office of Hawaiian Affairs ("OHA") ${ }^{74}$ would hold a part of the income and revenue from the lands granted to the state. ${ }^{75}$ Additionally, Section 7 of the Hawai' $i$ Constitution affirmed land rights of all Hawaiians, subject to State regulations. ${ }^{76}$ The HHCA adoption section stated that these lands would benefit two groups: "the native Hawaiians and Hawaians"; all real or personal property was set aside for native Hawaiians and Hawaiians. ${ }^{77}$

The shifts Hawai' $i$ experienced between the arrival of Captain Cook in 1778 to statehood in 1959 impacted many things - culture, social structure, and the governmental system to name a few. One of the biggest and most lasting effects of this transformation has been its impact on Native Hawaiian health.

\section{B. Hawaiian Health}

Though Hawaiian health has significantly improved over the past sixty years, Hawaiian health professionals remain concerned about challenges faced by the Hawaiian population. ${ }^{78}$ To understand why, we must look back at the history of Hawaiian health. Ancient Hawaiian history suggests that Hawaiians were physically fit and strong from their labor and had low-fat, high-carbohydrate diets. $^{79}$ The traditional Hawaiian diet consisted of "a high amount of complex carbohydrates $(78 \%)$, a moderate amount of protein $(12 \%)$, and a small amount of fat (10\%)." ${ }^{\prime 80}$ In a 1963 study, diabetes rates were six times higher in Hawaiians living in Hawai' $i$ than Caucasians living in Hawai $i{ }^{6}{ }^{81}$ Full blooded Hawaiians were found to have a diabetes prevalence rate of $48.8 \%$ while part Hawaiians had

73. Id.

74. Melody Kapilialoha MacKenzie, Native Hawaiians and US Law, in Native Hawaiian Law: A Treatise 273-74 (Melody Kapilialoha MacKenzie et al. eds., 2015). HAW. REV. STAT. §10-6 (2018). OHA was established by the Hawai' $i$ Constitution in 1978 "to reaffirm the state's obligation with regard to the public land trust, the former Government and Crown Lands of the Hawaiian Kingdom." OHA has many powers, such as the power to obtain and oversee property and create public policies regarding Hawaiian issues. Further, OHA is a state agency that is independent from all branches of government and self-governs with a board of trustees.

75. HAw. CONST. art. XII, $\S 6$.

76. HAW. CONST. art. XII, $\S 7$.

77. HAW. CONST. art. XII, $\S 4$.

78. Email from Joseph Gonsalves, Exec. Dir., Hui No Ke Ola Pono, to author (Sept. 21, 2018, 14:36 EST) [hereinafter Email] (on file with author).

79. Jane H. Lassetter, The Integral Role of Food in Native Hawaiian Migrants' Perceptions of Health and Well-Being, 22 J. Transcultural Nursing, 63, 63-64 (2011).

80. Id. at 64 .

81. Norman R. Sloan, Ethnic Distribution of Diabetes Mellitus in Hawai ${ }^{i}$, 183 J. Am. MED. Ass'N, 419, 419 (1963). 
a diabetes prevalence rate of $26.6 \%{ }^{82}$

By 1998 , the poor health conditions of urbanized native populations in the Pacific had been properly recorded, yet, there was little to no information about fruitful strategies to promote health within those populations. ${ }^{83}$ Because "medically competent" healthcare professionals may not be aware of the correlation between lifestyle choices and recurring illnesses, they cannot treat native patients adequately. ${ }^{84}$ Illnesses such as diabetes and hypertension were unusual in Pacific Islanders before Westernization caused a shift in diet and a decrease in physical activity. ${ }^{85}$

In a 2008 study of Hawaiians, Filipinos, Japanese, and Caucasians living in Hawai' i, Hawaiian participants had the highest caloric intake out of all the ethnic groups as well as higher body mass indexes and higher waist-to-hip ratios than both Japanese and Caucasian participants. ${ }^{86}$ These health issues can be attributed to the impact of Westernization on many ethnic (specifically, native) groups:

the change away from traditional foods to high fat, high calorie, low fiber, refined foods, canned meats, imported food products and alcoholic beverages has resulted in significantly higher prevalence rates of obesity, cardiovascular disease, high blood cholesterol levels, glucose intolerance and the eventual occurrence of Type II diabetes mellitus within these ethnic populations. ${ }^{87}$

Luckily, there are now organizations and programs in place to actively combat the negative health impact of Westernization on Native Hawaiians, such as Traditional Hawaiian Diet programs.

Traditional Hawaiian Diet ("THD”) programs began in 1987 and eventually became part of successful intervention programs that remedy the effects of illnesses, especially diabetes cardiovascular disease, and high blood pressure. ${ }^{88}$ THD programs normally last for three weeks and aim to teach obese and chronically ill participants about several things, including the culture and value surrounding traditional Hawaiian foods, portion sizes, and cooking techniques. ${ }^{89}$ The first implemented THD program was the Moloka"i Diet Study ("MDS") in 1987; the MDS involved meals of traditional Hawaiian foods, such as "fresh fish and occasionally chicken, taro[], sweet potatoes, yams, breadfruit, seaweed, bananas, taro leaves and sweet potato leaves, and several native greens."

The most well-known THD program is the Wai'anae Diet Program ("WDP"), established in 1989; participants only consume pre-Western contact Hawaiian

82. Id. at 419-24.

83. See generally Hughes, supra note 9.

84. See id. at 329.

85. See id. at 330.

86. See Lassetter, supra note 79 , at 64-65.

87. Hughes, supra note 9, at 328-29.

88. See id. at 330.

89. See id. at 329.

90. Id. 
foods, with the exception of a controlled amount of protein..$^{91}$ The main sources of protein were fresh fish and sometimes chicken, similar to the MDS. ${ }^{92}$ In its very first study, the WDP served ten men and ten women whose average body mass index was 39.6 (a body mass index of 30 or higher is considered obese), and the average weight loss was $7.8 \mathrm{~kg}$ (about 17 pounds). ${ }^{93}$ Moreover, blood pressure levels and chronic asthmatic symptoms decreased amongst participants as a result of the first WDP. ${ }^{94}$

Further, two of the six diabetic participants completely stopped taking their diabetes medication simply by sticking to the THD; subsequent WDP's have yielded similar results to that of the first WDP. ${ }^{95}$ To even the non-academic or non-biased eye, the WDP demonstrates that consuming foods conducive to the THD is a beneficial way to lessen the effects of chronic illnesses such as obesity and diabetes.

In 2001, the first three-phase Uli'eo Koa Program incorporated THD and evaluated the wellness and physical health effects of the THD component. ${ }^{96}$ The Uli'eo Koa Program offered similar information as the MDS and WDP on what a THD consists of: the THD is composed of $78 \%$ carbohydrates, $12 \%$ protein, and $10 \%$ fat. ${ }^{97}$ Pre-contact Hawaiians had a predominately plant-based diet, consisting of "starchy and leafy green vegetables, a few fruits, moderate amounts of protein, and minimal fat." ${ }^{\text {"9 }}$ Examples of carbohydrate sources consumed by Ancient Hawaiians are taro and breadfruit; examples of leafy greens sources are taro leaves and seaweed; examples of fruit sources are bananas and mountain apples; examples of protein sources are fish and shellfish; and examples of fat sources are coconut and chicken. ${ }^{99}$

The Uli'eo Koa Program report emphasized that taking preventative measures to preserve and benefit Native Hawaiian health is just as important as mediating the effects of illnesses such as obesity and diabetes. ${ }^{100}$ The report also concluded that the nutrients provided within this modified THD exceeded the National Resource Council dietary standards. ${ }^{101}$ The diets of koa (warriors) were that of the plant-based THD and these warriors had both strength and stamina. ${ }^{102}$ So, there is little reason to believe that the THD would not provide the same benefits for

\section{See id.}

92. See id.

93. See id.

94. See id.

95. Id.

96. See generally Jodi Haunani Leslie, Uli eo Koa Program: Incorporating a Traditional Hawaiian Dietary Component, 8 PaC. Health Dialog 401 (2001).

97. See id. at 402.

98. Id.

99. See id.

100. See id. at 405.

101. See id. at 406 .

102. See id. at 405 . 
athletes, laborers, adults, and children of today.

An interesting note made in the Uli'eo Koa Program report is that, various traditionally Hawaiian foods could not be served at every meal due to their "high cost and limited availability" [emphasis added]. ${ }^{103}$ Because of this, food substitutes had to be used; for example, instead of poi and fish, brown rice and lean chicken were served in daily meals. ${ }^{104}$ It is odd that foods with demonstrated health benefits over the course of at least 200 years are of "high cost and limited availability." It appears that Westernization did not only result in a loss of land, culture, and identity, it resulted in a loss of good health. Thankfully, there are now a number of Hawaiian organizations trying to incorporate or mimic THD programs into their projects.

Hui No Ke Ola Pono, located on Maui, is "one of five Native Hawaiian Health Care Systems created under the Native Hawaiian Health Care Act of 1988 and reauthorized under the Native Hawaiian Health Care Improvement Act of 1992." ${ }^{105}$ Joseph Gonsalves, the executive director of Hui No Ke Ola Pono, remains concerned about the health of the indigenous people of Hawaii:

Statewide and on Maui, the Native Hawaiian population has been adversely affected by unmet needs and poor health indicators ... By 2010, Native Hawaiians had the highest diabetes mortality rates either as an underlying cause of death (UCD) or contributing cause of death (CCD) (Hawaii Diabetes Report 2010, Hawaii Department of Health). Eight primary diseases related to metabolic dysfunction include type 2 diabetes, hypertension, lipid problems, heart disease, non-alcoholic fatty liver disease, polysystic ovarian syndrome, cancer, and dementia. Obesity is a marker for all of them, and these eight diseases account for a staggering 75 percent of the healthcare costs in the US. ${ }^{106}$

Hui No Ke Ola Pono received \$3.1 million in federal funding for 2018, and as a result of this generous amount of money, they were able to create more services and programs for Maui's Native Hawaiian community. ${ }^{107}$

Gonsalves provided an in-depth look at what exactly Hui No Ke Ola Pono does for the Maui community:

The Hui's Nutrition Program is unique with the "Simply Healthy Cafe'" providing nutritional outreach education and cooking demonstrations to all ages in the community[,] using the diet standards of the modified Native Hawaiian Diet Program (Mea 'Ai Pono)...The Café also does special catering for cultural and community groups who have ask[ed] for their members to experience Mea 'Ai Pono for the first time. The Physical Exercise Program ('Eleu) provides several avenues for exercise

103. Id. at 403 .

104. See id.

105. Who We Are, Hui No Ke Ola Pono, http://hnkop.org/about-us/who-we-are/ [https:// perma.cc/3L4E-W3GL].

106. Email, supra note 78 (emphasis added).

107. Id. 
such as walking, hulacise ["hula-exercise"], gym facility and swim aerobics ... The Mea "Ai Pono program also has an exercise component. Health Education and Disease Prevention Presentations are offered to the community and client groups, along with Community Health Screening and Wellness Events. A major delivery method for the Hui is through health fairs. The Hui, in partnership with other organizations will be collaborating in health fairs, participating with display, information[,] and enrollment booths. Other programs that will be included: vital health screenings, including, eye, dental and medical screening exams, through a cadre of medical doctors, a dentists and allied health professionals. ${ }^{108}$

Though Hui No Ke Ola Pono is a Native Hawaiian healthcare system, it services the entire Maui community to improve the overall health and wellness of our island. And as mentioned earlier in this Note, a necessary tool to improving the health of both Hawaiians and the Hawai'i community as a whole is land. MA'O Organic Farms, a "community food systems initiative" on $\mathrm{O}^{\prime}$ ahu, has stated: "[h]igh rates of food insecurity and diet-related health disparities have long impacted Hawai' $i$, while much prime agricultural land lays idle or slated for urban development." ${ }^{109}$ In other words, access to agricultural land is key in improving Hawaiian health, and improving indigenous health in this way is the goal of food sovereignty.

\section{FOOD SOVEREIGNTY: THE INTERSECTION OF HAWAIIAN LAND RIGHTS AND HEALTH}

\section{A. The Concept of Food Sovereignty}

Food sovereignty is where Native Hawaiian land rights and Native Hawaiian health intersect. Dr. Kyle Powys Whyte, a Philosophy professor at Michigan State University, noted: "[t]o understand this concept of food sovereignty, it is critical to be able to connect settler colonialism with the ecological value of food."110 Whyte cited to the Detroit Food Justice Task Force and described food sovereignty as freeing up land to generate food for the community, which in turn, creates designs for "collective control of land and waterways." 111 Further, food sovereignty "includes the true right to food and to produce food, which means that all people have the right to safe, nutritious and culturally appropriate food and to food-producing resources and the ability to sustain themselves and societies." 112 At the 1996 World Summit, La Via Campesina defined food

108. Id.

109. Growing Our Farm to Grow Our Youth, MA`O ORGANIC FARMS, https://perma.cc/93LMSU9X.

110. Kyle Powys Whyte, Indigenous Food Sovereignty, Renewal and U.S. Settler Colonialism, in Routledge Handbook of Food Ethics 354, 354 (Mary Rawlinson \& Caleb. Ward eds., 2016).

111. Id.

112. BeLL-SHEETER, supra note 11 , at 4 . 
sovereignty as "the right of each nation to maintain and develop their own capacity to produce foods that are crucial to national and community food security, respecting cultural diversity and diversity of production methods." 113

The concept of food sovereignty normally operates in the context of indigenous rights. For instance, federally recognized Indian tribes ensured their rights to harvesting foods on treaty-enforced ceded lands by using "Englishlanguage concepts and frames associated with concepts of inherent sovereignty, self-determination, cultural integrity, subsistence harvesting, and treaty rights as ways of justifying their own control over foods that matter culturally, economically, and nutritionally."114

Additionally, the First Nations Institute stated:

Control of Native food systems is intricately connected to control of Native assets, and increased Native control of agricultural assets is an important strategy for increasing control of Native food systems . . . Because the federal government and the Bureau of Indian Affairs (BIA) hold this land in trust for Native peoples, individuals and tribal governments often have little say in how their land is used or have little experience managing land for agricultural pursuits. ${ }^{115}$

Essentially, native peoples hold quite a bit of land in trust but do not control how it is used, and thus are unable to use it for traditional agricultural purposes to promote physical, spiritual, and cultural health. ${ }^{116}$ A similar problem plagues Native Hawaiians, with the key difference being that Hawaiians do not own a majority of their land and were unable to secure any sort of agricultural rights to the ceded lands. ${ }^{117}$

Notably, most of the food available in Native communities is supplied by either the federal government or non-Native businesses, with a small number of prosperous, locally-supported agriculture endeavors. ${ }^{118}$ Similar to that of Native American communities, Native Hawaiians depend on traditional foods and connection with the land for strengthening physical, cultural, and spiritual health. ${ }^{119}$ In analyzing testimony from several native voices, Dr. Whyte observed

113. Whyte, supra note 110 , at 355 .

114. Id. at 356. Casandia Bellevue, GMOS, International Law and Indigenous Peoples, 30 PACE INT'L L. REV. 1, 33-34 (2017). Moreover, a recent examination of food sovereignty in a native context noted: " $[\mathrm{t}] \mathrm{o}$ be food sovereign is much more complex, but essentially it means food autonomy, and it is based on sustainable agricultural practices and an ability to shapes one's own means of subsistence. By preventing or in any way interfering with traditional seed saving or cultivation practices, companies are effectively depriving indigenous peoples of their food sovereignty" (emphasis added).

115. BELL-SHEETER, supra note 11, at 12.

116. Id. See also Johnson v. Mcintosh, 21 U.S. 543, 562 (1823) ("The exclusive right of the British government to the lands occupied by the Indians, has passed to that of the United States.").

117. See Miller, supra note 13.

118. See Bell-SheEter, supra note 11 , at 8.

119. Id. at 9 . 
that indigenous people value food in a way that cannot be reduced to scientific nutritional quality measures. ${ }^{120}$ All the processes involved with food, from production to consumption, are "woven tightly with land tenure, a community's way of life, reciprocal gift giving and life sustenance, connecting people in a community, and respect for nonhuman life." ${ }^{21}$

Dr. Whyte went on to note the effects of settler colonialism ${ }^{122}$ on Native communities, particularly on Native food systems; settler colonialism interfered with the food systems' ability to supply a community with things such as "cultural integrity, freedom, food security, public health." 123 Therefore, food sovereignty is Dr. Whyte's solution for Native peoples to ensure their social, cultural, and physical health. ${ }^{124}$ For instance, the Anishinaabe people's food sovereignty with respect to wild rice is an intricate and robust relationship that allows the Anishinaabe to adapt to modern life while simultaneously perpetuating their cultural identity. ${ }^{125}$ Dr. Whyte concluded that food sovereignty is a "strategic process whereby foods that are renewed serve to engender ranges of adaptive options that are appropriate when confronted with the challenges of Indigenous erasure in settler landscapes." ${ }^{126}$ Likewise, for the Hawaiian people, farming and consuming traditional foods is a claim to sovereignty and identity. ${ }^{127}$

\section{B. Hawaiian Food Sovereignty}

Across the state of Hawai' $i$, farmers are attempting to both restore Hawaiian agriculture and "reorient the islands' economy and food system, around local, traditional, organic produce." 128 Danny Bishop, a member of Na Hui Kalo, a local organization dedicated to bringing back ancient farming methods, sees the efforts of Hawaiian food sovereignty as a responsibility to the keiki (children). ${ }^{129}$ Bishop reminisced on the success of Hawaiian agriculture in ancient times, expressing that crops such as kalo, Malay apples, bananas, and breadfruit were harvested for centuries and yielded enough to feed the entire population of Hawai $i{ }^{1}{ }^{130}$ But due

120. Whyte, supra note 110 , at 358.

121. Id.

122. Id. at 359-60. Dr. Whyte described settler colonialism as: "a structured process of erasing another population's range of adaptation options" in which colonizers imposed their own "homelands and futurity" in Indigenous lands. Essentially, settlement is a method for colonizers to eliminate Native peoples' ways of life to make it their land culturally, socially, and politically so as to make the Western way of life unavoidable.

123. Id. at 359 .

124. Id. at 16 .

125. Id. at 361-63.

126. Id. at 363 .

127. Miller, supra note 13.

128. Id.

129. See id.

130. Id. Bishop also made note of the stark contrast between the shared responsibility model of Hawaiian farming and the corporate pineapple and sugarcane farms that took over immense 
to the aftershocks of Captain Cook's arrival, the traditional food system was eventually eradicated and our population cut in half; Bishop believes Hawaiian farming plays an integral role in the revitalization of Hawaiian identity and health. ${ }^{131}$

However, this endeavor is not without hurdles: approximately $80 \%$ of crops grown in Hawai' $i$ are exported due to the modern-day "industrial monocrop" agriculture system. ${ }^{132}$ Fortunately, the number of taro farmers continues to grow, in an attempt to "regain[] lost knowledge" through traditional agriculture. ${ }^{133}$ For example, $\mathrm{MA}^{\prime} \mathrm{O}$ Organic Farms is actively reclaiming Hawaiian identity through farming. ${ }^{134}$ They commented on the islands' significant food dependency and risk of food insecurity, stating that Hawai'i imports $85 \%$ of its food and necessary elements to cultivate crops because "of global climate change, fuel price fluctuations and other economic disturbances." ${ }^{35}$ Daniel Anthony, a well-known poi pounder, articulated a powerful statement on food sovereignty for Hawaiians: "[e]ating is a powerful declaration of sovereignty. . . and the means by which Native Hawaiians will regain their independence." 136

As evidenced above, food sovereignty would enable Hawaiians to improve our overall health, revitalize our identity, and regain our independence. Yet, accessible agricultural lands in Hawai' $\mathrm{i}$ are scarce due to the impact of the largescale sugarcane plantations. ${ }^{137}$ The A\&B land empire illustrates this point.

\section{ALEXANDER \& BALDWIN CASE STUDY}

\section{A. The Beginning of Maui's Transition into Large-Scale Agriculture}

In 1869, Samuel Thomas Alexander and Henry Perrine Baldwin, both sons of missionaries, purchased 12 acres of land in Makawao on Maui island for $\$ 110$ to begin their sugar cane farming venture. ${ }^{138}$ In 1870, Alexander and Baldwin bought another 559 acres; six years later, the two men constructed an irrigation system that diverted water from Haleakalā (Maui's dormant volcano) to their sugar cane land in Central Maui. ${ }^{139}$ Once Alexander and Baldwin passed away, the company continued to acquire more land and develop water systems, and "these resources, initially acquired for agricultural purposes, would eventually

\footnotetext{
tracts of land on all the islands. "The chiefs had a reciprocal responsibility to the people and the environment ... And the people had that same reciprocal responsibility to the environment and the chief."

131. Id.

132. Miller, supra note 13.

133. Id.

134. See Growing our Farm to Grow our Youth, supra note 109.

135. Id.

136. Miller, supra note 13.

137. See MACKenZIE, supra note 5, at 17.

138. History, ALEXANDER \& BALDWIN, https://alexanderbaldwin.com/about/history/ [https://perma.cc/4D64-W8Y7].

139. Id.
} 
become the foundation of A\&B's strength and success today." 140

$A \& B$ is now one of the largest Hawai' $i$ real estate companies and has both commercial real estate and land development operations on Maui, O'ahu, Kaua'i, and the mainland. ${ }^{141}$ They "own, operate and manage 3.4 million square feet of retail, industrial, and office space in Hawaii . . . . and [are] the largest owner of grocery and drug-anchored retail centers in the state." 142 In other words, it appears as though $\mathrm{A} \& \mathrm{~B}$ has evolved past being a primarily agricultural company, so the 2016 Maui sugarcane production shutdown brought speculation on what would be done with the land.

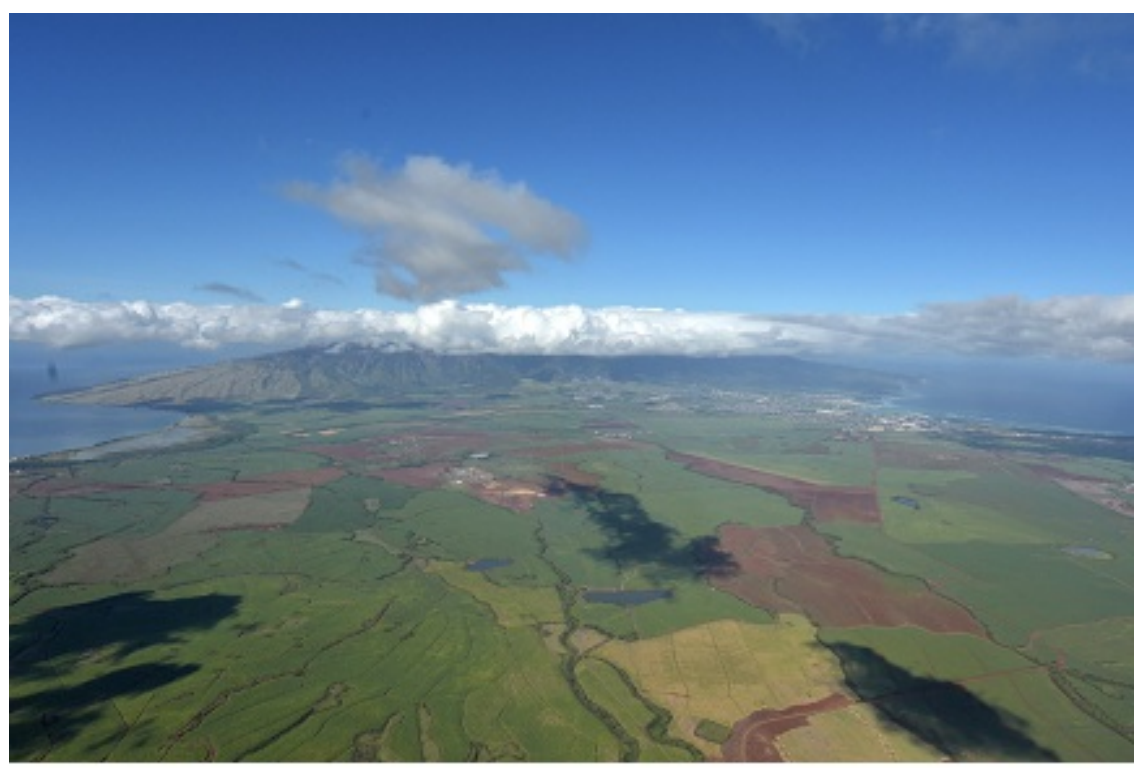

Pictured Above: Alexander \& Baldwin Lands; Credit: Maui News

\section{B. A Further Departure from Food Sovereignty on Maui}

After announcing its decision to stop producing sugar cane, A\&B received backlash from farmers, locals, and activists as a result of the shutdown. ${ }^{143}$ In the

140. Id.

141. See Alexander \& Baldwin, Inc. , AleXander \& Baldwin 2017 Annual Report + FORM 10K 4-5 (2018), http://investors.alexanderbaldwin.com/static-files/2f648544-5459-46909134-d651c2ad4725 [ https://perma.cc/ZS99-SAG6].

142. About, Alexander \& BALDWin, https://alexanderbaldwin.com/about/ [https://perma.cc/TD6W-HW56].

143. Stephen McLaren, Hawaii's Last Sugar Harvest Paves the Way for a Fight Over the Land's Future, GuARDian (Apr. 28, 2016), https://www.theguardian.com/usnews/2016/apr/28/maui-hawaii-sugar-cane-crops-agriculture-hcs-monsanto [https://perma.cc/S2JL- 
press release announcing the end of sugar cane production, $A \& B$ stated that it planned to divvy up the land into smaller farms for "varied agricultural uses." 144 Specifically, A\&B planned to use the land for things such as: "biogas feedstock crops," "pongamia orchards," and beverage crops. ${ }^{145}$ The most fascinating part of A\&B's plan was an agricultural park component:

A\&B plans to establish an agriculture park on former sugar lands in order to provide opportunities for farmers to access these agricultural lands and support the cultivation of food crops on Maui. HC\&S employees will be given preference to lease lots from the company to start their own farming operations. ${ }^{146}$

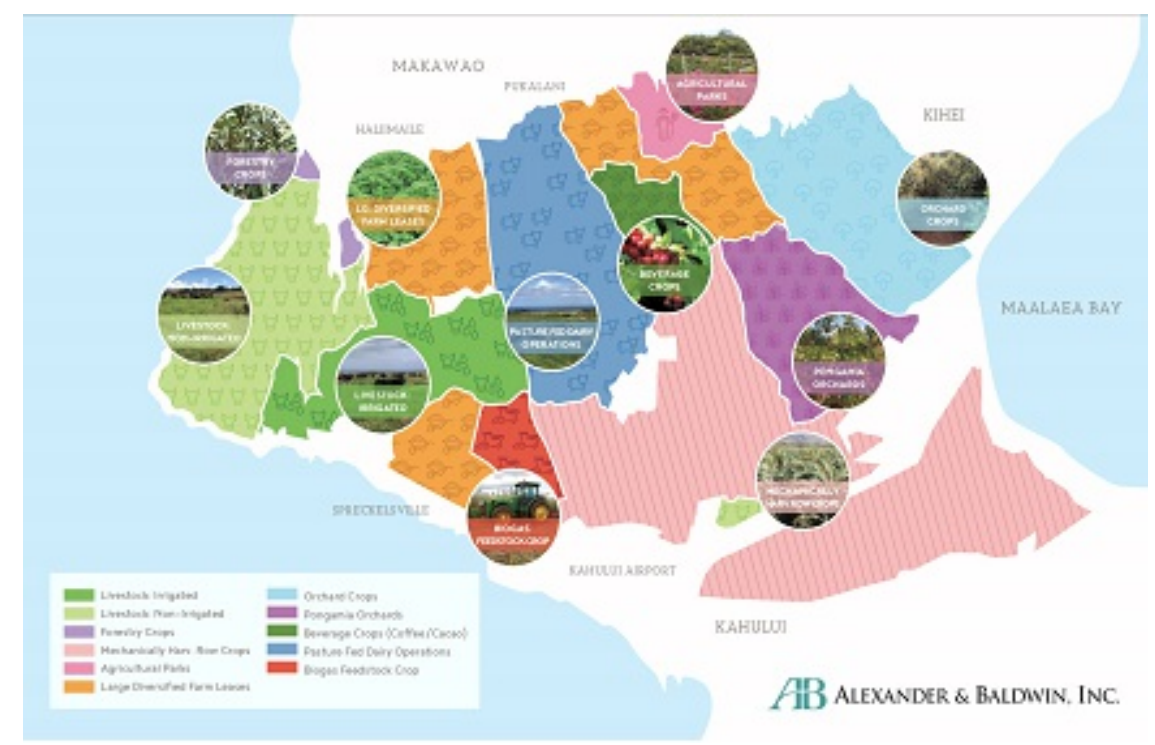

Pictured Above: 2017 Proposed Agricultural Plan; Credit: Alexander \& Baldwin, Inc.

This press release seemingly gives hope to the possibility of achieving food sovereignty - Maui farmers who grow traditional Hawaiian crops would have access to land that has been out of their grasp for years.

Since 2016, A\&B has entered into discussions with "hundreds" of interested parties, most of whom intended to grow one crop on only parts of the plantation

JVMP].

144. Press Release, Alexander \& Baldwin, Alexander \& Baldwin Announces Transition of Hawaiian Commercial \& Sugar Company to A Diversified Farm Model (Jan. 6, 2016), http://investors.alexanderbaldwin.com/news-releases/news-release-details/alexander-baldwinannounces-transition-hawaiian-commercial-sugar [https://perma.cc/NV9Y-953D] [hereinafter Transition].

145. See Imada, supra note 15.

146. Transition, supra note 144. 

SOVEREIGNTY AND HAWAIIAN HEALTH

land. ${ }^{147}$ The company eventually found Mahi Pono, a startup farming venture company resulting from the efforts of a California-based agricultural group, Pomona Farming, LLC, and a Canadian pension investment manager, Public Sector Pensions Board. ${ }^{148}$ According to Pomona Farming's website, "Maui Pono is a Maui Farming Company dedicated to transforming 41,000 acres of vacant former sugarcane land and 15,000 acres of watershed into a thriving hub of diversified agriculture, community engagement, and local employment." ${ }^{149}$ Mahi Pono is based out of Wailuku, Maui and consists of A\&B's former diversified agriculture employees, East Maui Irrigation employees, and a handful of experienced farmers. ${ }^{150}$

Mahi Pono also intends to utilize the land to "operate the property as a large diversified agriculture farm" and is considering including crops that are part of the traditional Hawaiian diet. ${ }^{151}$ The first phase of Mahi Pono's plan is to open a community agriculture farm, one of A\&B's original goals after stopping sugar cane production. ${ }^{152}$ This community farm would provide one, five, and ten-acre tracts of land to Maui farmers, who currently have crops but are in need of land and water for crop rotation; the farmers would also have access to Mahi Pono's "equipment, management, budgeting and marketing services." ${ }^{153}$ Additionally, the community farm would reserve plots for research, offer collegiate and high school internships, and have an advisory board made up of locals who would determine the rules for the farm. ${ }^{154}$ As of February 2019, Mahi Pono planned on implementing their first round of agricultural endeavors by planting "leafy green vegetable crops" within six to eight months. ${ }^{155}$

Mahi Pono's plans create both hope and skepticism within the Maui community; particularly, Maui residents are concerned about transparency for what exactly will be grown and the disproportionately high costs of farming on

147. Press Release, Alexander \& Baldwin, A\&B agreement with Mahi Pono launches new era of agriculture on Maui (Dec. 20, 2018), http://investors.alexanderbaldwin.com/news-releases/newsrelease-details/ab-agreement-mahi-pono-launches-new-era-agriculture-maui [https://perma.cc/KYK8-B5WX] [hereinafter Press Release].

148. Mahi Pono Purchase of Former HC\&S Lands Helps Ensure Agricultural Future for Maui, Business WIRE (Dec. 20, 2018, 5:01 PM), https://www.businesswire.com/news/home/2018 1220005936/en/Mahi-Pono-Purchase-HCS-Lands-Helps-Ensure [https://perma.cc/KZ94-6FDU].

149. Projects, POMONA FARMING, https://pomonafarmingllc.com/projects/ [https://perma. cc/QG7S-RY2U].

150. Email from Grant Nakama, Operations Manager, Mahi Pono, to author (Feb. 1, 2019, 19:28 EST) (on file with author).

151. Id.

152. Colleen Uechi, Community Farm Near Mill in Mahi Pono Early Plans, Maui News (Feb. 1, 2019), http:/www.mauinews.com/news/local-news/2019/02/community-farm-near-mill-in-mahipono-early-plans/ [https://perma.cc/57S6-PEZR].

153. Id.

154. See id.

155. See id. (emphasis omitted). 
Maui. ${ }^{156}$ Brandon Sato, President of Kula Onions Etc., LLC and a long-time Maui farmer, observed that Maui County is the state's highest food importer because the costs of doing business for local farmers is quite high. ${ }^{157}$ However, Sato asserts that there is a niche for traditional Hawaiian crops (e.g. taro, taro leaves, and breadfruit) on Maui, but the biggest obstacle farmers face is obtaining land to compete with larger farms within the state and on the mainland. ${ }^{158}$

While Mahi Pono's 41,000+ acre purchase came as a surprise to the Maui community, 2018 also saw a shocking end to the 17-year battle over water rights between A\&B and Native Hawaiian farmers - the state Commission on Water Resource Management ordered the full restoration of ten of Maui's streams for kalo farming and limited diversion of seven more streams for habitat restoration. ${ }^{159}$ Moreover, in an August 2018 article published by Pacific Business News, A\&B agreed to sell over 300 acres of its agricultural land to the state of Hawai $i$ to expand the Kahului-Maui airport. ${ }^{160}$ Since shutting down its sugar cane production, A\&B has sold approximately 46,000 acres of land to Mahi Pono and reported profits of about $\$ 270$ million. ${ }^{161}$

It is also important to recognize how $A \& B$ was able to acquire its land in 1869 to better understand why the Mahi Pono land purchase is important. In other words, the events that allowed A\&B to make its original land purchase are critical to this argument.

According to James Podgers, former editor of the ABA Journal, before Hawaiian citizens voted for statehood in 1959, America took Hawai' $i$ off the United Nations' list of non-self-governing territories. ${ }^{162}$ The vote instead asked residents if Hawai'i should be admitted as a state. ${ }^{163}$ In 1996, Professor Richard Falk of the Center of International Studies at Princeton University wrote to sovereignty groups in Hawai' $i$, stating that: "“[i]t can...be concluded as a matter of law' that Native Hawaiians 'never relinquished, in any appropriate or binding form, their right to self-determination under international law." ${ }^{164}$ Many scholars and activists use international law to argue for Hawaiian rights, and there are three core theories based on international law pursued by these Hawaiian

156. See id.

157. Telephone Interview with Brandon Sato, President, Kula Onions Etc., LLC (Jan. 26, 2019).

158. Id.

159. Lee Imada, Taro Growers, Practitioners Elated with E. Maui Water Rights Decision, MaUi News (June 21, 2018), http://www.mauinews.com/news/local-news/2018/06/taro-growerspractitioners-elated-with-e-maui-water-rights-decision/ [https://perma.cc/J48J-CRV9].

160. Janis L. Magin, A\&B Selling Land for Airport Expansion, Maui Shopping Center in Separate Deals, PAC. Bus. NEws (Aug. 2, 2018, 9:02PM), https:/www.bizjournals.com/pacific/ news/2018/08/02/a-b-selling-land-for-airport-expansion-maui.html?ana=yahoo\&yptr=yahoo [perma.cc/WUP2-d5HQ].

161. Press Release, supra note 147.

162. James Podgers, Greetings From 'Independent' Hawaii, 83 A.B.A. J. 74, 76 (1997).

163. See id.

164. Id. 
groups. ${ }^{165}$ Thus, a concise analysis of Hawaiian case history and each advocacy theory will offer a clearer foundation for the relationship between Hawaiian health and food sovereignty.

\section{POTENTIAL LEGAL STRATEGIES TO ACCOMPLISH HAWAIIAN FOOD SOVEREIGNTY}

Without land, Hawaiians have no chance at food sovereignty. Without food sovereignty, Hawaiian health suffers from decreased availability of foods conducive to the THD. Fortunately, land can be reclaimed through sovereignty, federal recognition, and other rights-based theories. Each of these, as well as the cases leading up to their creation, is outlined below.

\section{A. An Abbreviated Case History}

In Price v. State of Hawaii, 764 F.2d 623 (9th Cir. 1985), a group called Hou Hawaiians sued the State under 28 U.S.C. $\$ 1362^{166}$ for "failing to expend any . . . funds "for the betterment of the conditions of native Hawaiians." 167 The 9th Circuit found that Hou Hawaiians did not qualify for jurisdiction under this section of the code because they were not federally recognized by the Secretary of the Interior and dismissed the case. ${ }^{168}$

Later, in Rice v. Cayetano, 528 U.S. 495 (2000), a non-Hawaiian citizen of Hawai' $i$ attempted to vote in the OHA election but was denied eligibility and brought suit. ${ }^{169}$ The Supreme Court found that the Hawaiian ancestry limitation violated Rice's right to vote because it was racially exclusive. ${ }^{170}$ Further, Native Hawaiians are not considered a "political group" like federally recognized tribes, so a racially exclusive vote is unconstitutional. ${ }^{171}$

Finally, in Kahawaiolaa v. Norton, 386 F.3d 1271 (9th Cir. 2004), plaintiffs sued the Department of Interior for precluding Native Hawaiians from the tribal acknowledgment process. ${ }^{172}$ The court concluded that the Department of Interior failed to adequately determine Native Hawaiians' eligibility for a government-togovernment relationship, but nevertheless left the question of eligibility for

165. Anaya \& Williams, supra note 24 , at 3.

166. 28 U.S.C. $§ 1362$ (2018) (giving federal district courts jurisdiction over lawsuits filed under federal law brought by federally recognized Native American tribes) (this section has not been amended since 1985, the year of the case being discussed).

167. Price v. State of Hawaii, 764 F.2d 623, 625 (9th Cir. 1985).

168. See id. at 626.

169. Rice v. Cayetano, 528 U.S. 495, 499 (2000) (stating that OHA's election process involves choosing nine members of Hawaiian ancestry to a board of trustees on four-year terms; at least one member each must be from Kaua'i, O'ahu, Moloka'i, Maui, and Hawaii Island) and a chairman and vice-chairman are elected by the board). MACKENZIE, supra note 74, at 273-74.

170. Rice, 528 U.S. at 522.

171. Id.

172. Kahawaiolaa v. Norton, 386 F.3d 1271, 1272 (9th Cir. 2004). 
Congress. ${ }^{173}$ Because Hawai'i has a unique history with the United States (when compared with Native Americans), Congress has created Native Hawaiian federal programs and benefits that differ from federally recognized tribes. ${ }^{174}$

\section{B. Three Hawaiian Advocacy Theories}

The commonality between the above cases is simple: the lack of federal recognition has precluded Hawaiians from asserting their rights for years. Yet, there are Hawaiians who seek to obtain recognition of our rights under international law. ${ }^{175}$ James Anaya, Dean of the University of Colorado-Boulder Law School and Robert Williams, Jr., professor at the University of Arizona College of Law, declared the following:

The duty of States (that, is independent States, in particular those that are members of the United Nations) to recognize indigenous peoples and to respect and protect their rights is well established under international law and policy. The United States has the responsibility to recognize and protect these rights and to provide remedies for their infringement. This responsibility applies toward Native Hawaiians, who unquestionably qualify as an indigenous people within the contemporary international understanding of the indigenous rubric. ${ }^{176}$

Rooted in this duty, Anaya and Williams outline three main schools of thought in the pursuit for Hawaiian rights: indigenous peoples' rights, decolonization, and sovereignty. ${ }^{177}$

\section{Indigenous Peoples' Rights Theory}

Per this view, the target is Native Hawaiians, and the United Nations Declaration on the Rights of Indigenous Peoples ${ }^{178}$ and international human rights

173. Id. at $1280,1282$.

174. Id at 1282. Programs include the Hawaiian Homes Commission Act and the Native Hawaiian Health Care Improvement Act.

175. See Anaya \& Williams, supra note 24, at ii.

176. Id. at i.

177. See id. at ii.

178. Id. at i, 4-5. The United Nations Declaration on the Rights of Indigenous Peoples ("Declaration") was adopted by the United Nations General Assembly in 2007. The United States, along with other independent states, voted against the Declaration, but it was later endorsed in 2010 by President Obama. The Declaration is not legally binding, but is legally important because:

[it] represents an authoritative synthesis of the human rights principles found in various treaties, beginning with the United Nations Charter, and their application to indigenous peoples . . . the Declaration can be seen as expressive of general principles of international law, both categories of law being, like treaties, binding on States.

Anaya and Williams call the Declaration a "remedial instrument" because its goal is remedying past dismissal of indigenous peoples' rights to self-determination so that they "may overcome systemic disadvantage and achieve a position of equality vis-à-vis heretofore-dominant sectors of society." 
law are the "sources of authority." 179 The goal is to safeguard Native Hawaiian rights in relation to culture, land, and self-governance within the American legal structure. ${ }^{180}$ According to Professor Erica Daes, the chair of the United Nations Working Group on Indigenous Populations, this approach highlights a process in which Hawaiians, in conjunction with the rest of the United States, could mutually agree upon terms to simultaneously observe their distinctness and include them "in the fabric of the State." "I81 In fact, the Declaration instructs States to collaborate with native peoples and take the proper actions to ensure indigenous rights and the objective of the Declaration. ${ }^{182}$ Furthermore, the Declaration compels States to afford "redress, by means that can include restitution or, when this is not possible, just, fair and equitable compensation" for seizing indigenous lands. ${ }^{183}$

The topic of food sovereignty also cites to the Declaration as a foundation; the Declaration specifies a number of basic rights indigenous peoples are entitled to, including "the right to maintain, control, protect and develop their cultural heritage, traditional knowledge and traditional cultural expressions . . . including human and genetic sources, seeds, medicines." 184 Further, Article 24(1) enumerates the right to "the conservation of their vital medicinal plants, animals, and minerals. ${ }^{185}$

The United Nations continues to develop its efforts to afford indigenous peoples more agricultural rights - in 2016, the United Nations enforced the "17 Sustainable Development Goals (SDGs)" set out in its 2030 Agenda For Sustainable Development. ${ }^{186}$ Its second SDG seeks to "achieve food security and improved nutrition and promote sustainable agriculture " in various ways. ${ }^{187}$ The most pertinent to the issue at hand is as follows: "[b]y 2030, double the agricultural productivity and incomes of small-scale food producers, in particular women, indigenous peoples [emphasis added], family farmers, pastoralists and fishers, including through secure and equal access to land [emphasis added],

179. Id. at ii.

180. Id. at 6 .

181. Id. Some mandated actions are: to establish a self-governance right in agreement with indigenous peoples' own cultures and political schemes; and to guarantee a right, if the indigenous peoples' so desire, to participate in the independent State's affairs. Additionally, States must obtain "free, prior and informed consent" from the indigenous people before approving any legislation or decision that may affect them.

182. Id.

183. G.A. Res. 61/295, United Nations Declaration on the Rights of Indigenous Peoples, art. 28(1) (Sept. 13, 2007).

184. Id. at art. 31(1).

185. Id. at art. 24(1).

186. See generally G.A. Res. 70/1, Transforming Our World: the 2030 Agenda for Sustainable Development (Sept. 25, 2015). The 2030 Agenda for Sustainable Development was adopted by the General Assembly in September 2015.

187. Id. at 15 . 
other productive resources and inputs, knowledge, financial services, markets and opportunities." 188

\section{Decolonization Theory}

Decolonization differs slightly from the indigenous peoples' rights regime; its target varies, but it is generally all residents of Hawai i $i$ who have "strong roots in the archipelago." 189 The "source of authority" for decolonization is Article 73 of the United Nations Charter along with other "related United Nations declarations and practice;" the goal is creating a mechanism in which Hawai' $i$ has the option to change its status to an independent nation-state..$^{190}$

Anaya and Williams point out that decolonization and the indigenous peoples' rights school of thought are both rooted in the self-determination right and remedying historical wrongs, however, decolonization focuses on getting rid of "conditions of classical colonialism in the administration of entire territories that are deemed non-self-governing." ${ }^{191}$ In essence, decolonization applies to colonized territories whereas the indigenous peoples' rights theory applies to "culturally differentiated indigenous peoples within both colonial territories and territories that are deemed fully self-governing as independent or parts of independent States." ${ }^{\prime 192}$

\section{Sovereignty and the Restoration of the Hawaiian Monarchy}

The sovereign Hawaiian monarchy is possibly the most popular theory pursued by Hawaiian activists; Anaya and Williams tell us that this theory is "grounded in the States-rights frame of international law (or the law of nations, as the discipline was often called in the late nineteenth-early twentieth centuries)" and rests "on a highly formalistic understanding of the law of nations." 193

188. Id.

189. Anaya \& Williams, supra note 24 , at 3 .

190. Id.

191. Id. at 15 .

192. Id. at 15-16. Hawai' $\mathrm{i}$ was considered a non-governing territory until it became a state in 1959; apparently the United States administered a plebiscite where people had to choose between either "the status quo" and statehood, but independence was not a choice. Interestingly, all United States citizens living in Hawai $i$, including those who had only lived there for a year, were eligible to vote. Hawai' $i$ was then taken off the United Nations General Assembly's list of non-selfgoverning territories. As a result, some Hawaiians demand for the reinclusion of Hawail $i$ on the General Assembly's list and another plebiscite.

193. Id. at 19. Anaya and Williams outline the movement in further detail:

the argument claims for Hawaii the sovereign prerogatives of an independent State under the monarchy that originated in King Kamehameha I and continued through successive heirs to the throne. Within this argument, the United States' presence in [the] Hawaii, which came about with the overthrow of the monarchy, represents an illegal occupation and hence the law of nations requires 'de-occupation' and effective 
Supporters of this theory rely on the 1993 Congressional Apology, which sought to make peace with Native Hawaiians for the "ramifications of the overthrow for the Kingdom of Hawaii." ${ }^{194}$ Moreover, activists in favor of the restoration of the Hawaiian monarchy contend that the United States' "assertion of sovereignty over Hawaii" is baseless under international law due to the "illegality" of the Overthrow. ${ }^{195}$ Anaya and Williams clarify that the indigenous peoples' rights theory endorses a "Hawaiian-led process toward restoration of the monarchy with some level of authority and shared sovereignty, by virtue of the rights of selfdetermination and self-government that are recognized in the UN Declaration and other sources." $" 196$

The previously discussed theories are grounded in international law, but it is also helpful to look into opportunities founded in American federal law.

\section{Federal Recognition}

The Bureau of Indian Affairs ("BIA") is the go-to federal resource for Native American, American Indian, and Alaska Native dealings. Their website states: "U.S. Supreme Court Chief Justice John Marshall articulated the fundamental principle that has guided the evolution of federal Indian law to the present: That tribes possess a nationhood status and retain inherent powers of selfgovernment. ${ }^{" 197}$ Consistent with this statement, in Seminole Nation v. U.S., the Supreme Court noted that the United States has legal and "moral obligations of the highest responsibility and trust" to Indian tribes. ${ }^{198}$ The Bureau of Indian Affairs further stipulated that, per this "federal Indian trust responsibility," the United States possesses a fiduciary obligation to "protect tribal treaty rights, lands, assets, and resources, as well as a duty to carry out the mandates of federal law with respect to American Indian and Alaska Native tribes and villages." 199

A federally recognized tribe is defined as a tribal entity, whether Alaska Native or Native American, "recognized as having a government-to-government relationship with the United States, with the responsibilities, powers, limitations, and obligations attached to that designation, and is eligible for funding and services from the Bureau of Indian Affairs." ${ }^{200}$ Federally recognized tribes also have self-government rights, such as sovereignty, and have financial assistance and certain protections as a result of their relationship with America. ${ }^{201}$ Currently,

restoration of the monarchy.

194. Id.

195. Id.

196. Id. at 21. But, it does not endorse the complete revival of the Hawaiian monarchy (should Hawai' $i$ achieve independence).

197. Frequently Asked Questions, supra note 25.

198. Seminole Nation v. United States, 316 U.S. 286, 297 (1942).

199. See Frequently Asked Questions, supra note 25.

200. Id.

201. Id. 
there are 573 federally recognized tribes, 229 of which are from Alaska. ${ }^{202}$

The process of federal recognition can be long and complicated; most tribes were able to obtain federal recognition through treaties, Acts of Congress, executive orders, federal court decisions, or federal administrative actions. ${ }^{203}$ The Office of Federal Acknowledgement ("OFA"), a branch of BIA, handles requests for federal recognition through the Federal Acknowledgment Process. ${ }^{204}$ Public Law 103-454, also known as the Federally Recognized Indian Tribe List Act of 1994, authorized three ways in which a tribe can achieve federal recognition: 1) by an Act of Congress; 2) administratively through 25 C.F.R. Part 83; or 3 ) by a United States court decision. ${ }^{205}$

As a reminder, Hawaiians have notoriously been excluded from going through the federal recognition process; however, 2016 brought about a new path for Hawaiians to pursue in the form of a federal rule. ${ }^{206}$ And this federal rule could be the first step towards Native Hawaiian food sovereignty.

\section{TYING IT ALL TOGETHER}

\section{A. The New Rule}

Every Hawaiian wants what is best for the community, but there are differing views on how to accomplish that - sovereignty, decolonization, indigenous peoples' rights, and federal recognition all have strong followings. ${ }^{207}$ Those who support federal recognition say that, because Native Hawaiians programs are being criticized as race-based by a Republican Congress, they no longer have federal traction. ${ }^{208}$ On the other hand, critics of federal recognition say that it is not enough, and "“anything short of self-determination is unprincipled, immoral[,] and illegal." ${ }^{209}$ However, Hawaiians struggle to achieve food sovereignty without federal recognition because no land entitlement means little possibility of enforcing traditional agriculture to benefit our indigenous community. ${ }^{210}$ Luckily, there seems to be hope on the horizon for Hawaiian food sovereignty with the passing of a new federal rule.

In November 2016, Hawai' $i$ and the United States made significant progress in providing Hawaiians with an opportunity to seek federal recognition equivalent

202. Id. Alaska Region, U.S. DEP'T INTERIOR: INDIAN AFFS., https://www.bia.gov/regionaloffices/alaska [https://perma.cc/EHR3-8NEA].

203. Id.

204. $I d$.

205. Federally Recognized Indian Tribe List Act of 1994, Pub. L. No. 103-454, §103-04 (1994).

206. See generally 43 C.F.R. $\S 50$ (2016).

207. See Rick Daysog, Na'i Aupuni Kicks Off Amid Heated Talks, HawAII NEws Now (Feb. 1, 2016, 3:22AM), http://www.hawaiinewsnow.com/story/31104257/nai-aupuni-kicks-off-amidheated-talks/ [https://perma.cc/FEU9-KDYC].

208. Id.

209. Id.

210. See Whyte, supra note 110 , at 354 . 

SOVEREIGNTY AND HAWAIIAN HEALTH

to that of Native American tribes with the enactment of 43 C.F.R. $\S 50$, or the Procedures for Reestablishing a Formal Government to Government Relationship with the Native Hawaiian Community. According to the executive summary, the rule:

establishes the Secretary['s] ... administrative process for reestablishing a formal government-to-government relationship with the Native Hawaiian community to more effectively implement the special political and trust relationship that Congress established between that community and the United States. The rule does not attempt to reorganize a Native Hawaiian government or draft its constitution, nor does it dictate the form or structure of that government. Rather, the rule establishes an administrative procedure and criteria that the Secretary would use if the Native Hawaiian community forms a unified government that then seeks a formal government-to-government relationship with the United States. Consistent with the Federal policy of self-determination and selfgovernance for indigenous communities, the Native Hawaiian community itself would determine whether and how to reorganize its government. ${ }^{211}$

In 2010, the House passed a bill discussing Native Hawaiian government reorganization that was backed by bills from the Senate Committee on Indian Affairs and the Executive Branch. ${ }^{212}$ The bill provided guidelines for a Native Hawaiian government, which included self-governing rights under current Indian law; it afforded Hawaiians protection under the Indian Civil Rights Act of 1968 and stated that the Native Hawaiian government was ineligible for Federal Indian programs without specific congressional intent. ${ }^{213}$ Further, the bill created a process in which Native Hawaiians could have the ability to "reorganize a single unified Native Hawaiian governing entity." 214

Then, in 2011, Act 195 created the Native Hawaiian Roll Commission (also known as Kana'iolowalu), which was the State government's way of supporting the creation of a Native Hawaiian government eligible for federal recognition. ${ }^{215}$

211. Procedures for Reestablishing a Formal Government to Government Relationship with the Native Hawaiian Community, 81 Fed. Reg. 71278 (Oct. 14, 2016) (codified at 43 C.F.R. pt. 50).

212. The bills, however, were not enacted. See id. at 71283. See generally Native Hawaiian Government Reorganization Act of 2010, H.R. 2314, 111th Cong. (2010); Native Hawaiian Government Reorganization Act of 2009, S.1011, 111th Cong. (2010); Native Hawaiian Government Reorganization Act of 2010, S.3945, 111th Cong. (2010).

213. Procedures for Reestablishing a Formal Government to Government Relationship with the Native Hawaiian Community, 81 Fed. Reg. at 71283-84.

214. Id. at 71284. But see id. (stating there are still congressional members who prefer that Hawaiians go through the normal federal acknowledgment process).

215. Id. Act 195 acknowledged Native Hawaiians as the only aboriginal people of Hawai $i$ and established a process for "compiling a roll of qualified Native Hawaiians to facilitate the Native Hawaiian community's development of a reorganized Native Hawaiian governing entity." 
Kana iolowalu made an initial list of over 95,000 qualified Native Hawaiians who were either "pre-certified" on any list managed by OHA or registered directly with Kana'iolowalu. ${ }^{216}$

However, Act 195, Kana iolowalu, and the 2010 U.S. House bill are independent of 43 C.F.R. Part $50 .{ }^{217}$ The rule recognizes that the "continuity of the Native Hawaiian community" has been acknowledged by Congress in "over 150 separate statutes, which ensures it has a special political and trust relationship with the United States;" still, "a working relationship between government officials is absent." 218 It explains that this relationship has yet to exist because 1893 (the year of the Overthrow) is the last time Native Hawaiians had an organized government; the rule admits the Overthrow occurred "when a United States officer, acting without authorization of the U.S. government, conspired with residents of Hawaii to overthrow the Kingdom of Hawaii." 219

The final rule leaves the responsibilities of "convening a constitutional convention ... drafting a constitution or other governing document for the Native Hawaiian government ... registering voters for purposes of ratifying that document ... electing officers for that government" to the Native community and precludes federal government involvement. ${ }^{220}$ If a Native Hawaiian governing body is established, it would enjoy the same relationship as that between the United States and federally-recognized tribes, subject to limitations on certain programs, services, and benefits. ${ }^{221}$

The rule also identifies the two different definitions of "Native Hawaiian;" under the Hawaiian Homes Commission Act, a Native Hawaiian is someone of at least 50\% Hawaiian ancestry (otherwise known as "HHCA Native Hawaiians" in the rule). ${ }^{222}$ The other definition (known as "Native Hawaiians" in the final rule) is anyone "who is a descendant of the aboriginal people who, prior to 1778 , occupied and exercised sovereignty in the area that now constitutes the State of Hawaii." ${ }^{223}$ The required proof to be classified as an HHCA Native Hawaiian is

216. Id. Kana iolowalu has since certified additional lists of qualified Native Hawaiians available online on their website. Certified List as of October 19, 2015, KANA'IOLOWALU (Oct. 19, 2015), http://www.kanaiolowalu.org/list/ [https://perma.cc/4PW6-CLQX].

217. Procedures for Reestablishing a Formal Government to Government Relationship with the Native Hawaiian Community, 81 Fed. Reg. at 71284.

218. Id. at 71278 .

219. Id. at $71278-79$.

220. Id. at 71285. The federal government is to only be involved when evaluating the satisfaction of the rule's requirements and having the Secretary of the Interior decide whether to restore a formal government-to-government relationship with the newly created Native Hawaiian government.

221. Id. at 71286. The rule also stipulates that the Native Hawaiian government would "be subject to the same plenary authority of Congress" and would "have the same inherent sovereign governmental authorities" as federally recognized tribes.

222. Id. See also Haw. Rev. Stat. § 10-2 (2018).

223. Procedures for Reestablishing a Formal Government to Government Relationship with the Native Hawaiian Community, 81 Fed. Reg. at 71286. See also HAw. Rev. STAT. § 10-2 (2018). 

SOVEREIGNTY AND HAWAIIAN HEALTH

"documentation demonstrating eligibility under HHCA sec.201(a)(7) . . such as official Department of Hawaiian Home Lands (DHHL) records or other State records. ${ }^{" 224}$ To satisfy the Native Hawaiian classification, the rule requires several things, including generational descent records verified by a state agency or through a Kamehameha Schools program. ${ }^{225}$

Additionally, this part expresses the federal government's inability to take land into trust for the potential Native Hawaiian government; the 1934 Indian Reorganization Act $^{226}$ does not apply to Hawai' $i$, so the Secretary of Interior has no power to take lands into trust. ${ }^{227}$ Finally, the final rule lists the seven required elements needed to submit a request to the Secretary of Interior to reestablish a formal government-to-government relationship. ${ }^{228}$ These elements include documentation detailing how the Native Hawaiian community drafted the governing document; documentation detailing who was chosen to ratify the document and why; the actual ratified governing document; and a detailed description of the election process for the government officials listed in the governing document. ${ }^{229}$

According to Professor Melody Kapilialoha MacKenzie, law professor at the University of Hawai'i at Mānoa William S. Richardson School of Law and chief editor and author of a number of chapters in Native Hawaiian Law: A Treatise, the Native Hawaiian community held a constitutional convention in February 2016 with participation from those who had signed up on the roll established through Act 195 and the Kana iolowalu process. ${ }^{230}$ She relayed that a constitution was drawn up and the idea was to raise funds, do educational outreach in the Native Hawaiian community, and eventually hold a ratification vote on the constitution. ${ }^{231}$ Unfortunately, after the 2016 election, and given the uncertainty

224. Procedures for Reestablishing a Formal Government to Government Relationship with the Native Hawaiian Community, 81 Fed. Reg. at 71286.

225. Id. at 71285-86 ("A Native Hawaiian may also sponsor a close family relative through a sworn statement attesting that the relative meets the definition of Native Hawaiian. Enumeration in official DHHL records demonstrating eligibility under the HHCA also would satisfy the definition of 'Native Hawaiian,' as it would show that a person is an HHCA Native Hawaiian and by definition a 'Native Hawaiian' as that term is used in this rule.").

226. See generally 25 U.S.C $\S 5108$ (2018). This section of the Indian Reorganization Act allows the Secretary of Interior to acquire "through purchase, relinquishment, gift, exchange, or assignment, any interest in lands, water rights, or surface rights to lands, within or without existing reservations, including trust or otherwise restricted allotments, whether the allottee be living or deceased, for the purpose of providing land for Indians."

227. Procedures for Reestablishing a Formal Government to Government Relationship with the Native Hawaiian Community, 81 Fed. Reg. at 71291.

228. 43 C.F.R. $\S 50.10$ (2019).

229. Id.

230. Interview, supra note 23.

231. Id. A private nonprofit organization put on the constitutional convention based on those 
of federal policy following President Trump's election, funding became much more difficult. ${ }^{232}$

In making a decision, the Secretary of Interior will consider various factors; besides the seven required components, the Secretary will examine the number of votes cast in favor of the governing document by Native Hawaiians if it "exceeded half of the total number of ballots that Native Hawaiians cast in the ratification referendum," as long as the amount of votes were enough to "demonstrate broad-based community support among Native Hawaiians." 233 Curiously, the rule also states that the amount of votes cast by HHCA Native Hawaiians will be considered separately. ${ }^{234}$

\section{B. Criticisms}

While this rule is an impactful step in adjusting the relationship between the United States and Hawai' $i$, it is not perfect. For example, relevant criticism of this rule dealt with land status; $\S 50.44(\mathrm{f})$ declares: "Reestablishment of the formal government-to-government relationship does not affect the title, jurisdiction, or status of Federal lands and property in Hawaii." ${ }^{235}$ Several comments objected to this section of the rule and requested transferring some federal lands to the Native Hawaiian government. ${ }^{236}$ The response is that there is a future possibility for the Native Hawaiian government to secure federal land under certain federal laws, but any revisions to entitlement to federal lands calls for congressional actions. ${ }^{237}$

Related to the theme of this Note, commenters indicated the significance of allowing a future Native Hawaiian governing entity to hold land entitlements because of our spiritual connection to our land. ${ }^{238}$ The response points to the possibility that a potential Native Hawaiian sovereign could obtain property through other means not enumerated in the rule. ${ }^{239}$ Also, many comments on the

who said they wanted to run as potential Native Hawaiian sovereign officials as a result of Act 195 being challenged in court.

232. Id.

233. 43 C.F.R. $\S 50.16(\mathrm{~g})$ (2019). If there are less than 30,000 votes are cast in favor of the document, then this element is considered unsatisfied; conversely, if more than 50,000 votes are cast in favor of the document, the element is presumed to be satisfied.

234. 43 C.F.R. $\S 50.16(\mathrm{~h})$ (2019). Similar to $\S 50.16(\mathrm{~g})$, this section of the rule says that the votes in favor of the governing document must exceed half of the total number of votes, as long as the total number of votes were enough to show Native Hawaiian community approval. Further, if less than 9,000 HHCA Native Hawaiian votes are cast in favor of the document, the element is unsatisfied; if more than 15,000 HHCA Native Hawaiian votes are in favor of the document, the element is presumed to be satisfied.

235. 43 C.F.R. § 50.44(f) (2019).

236. Procedures for Reestablishing a Formal Government to Government Relationship with the Native Hawaiian Community, 81 Fed. Reg. at 71305.

237. Id. at 71306 .

238. Id. at 71305 .

239. Id. at 71305. The rule gives the example of a state provision allowing the transfer of Kaho" olawe "to the sovereign native Hawaiian entity upon its recognition by the United States and 
final rule criticize the distinction between Native Hawaiians and HHCA Native Hawaiians, calling for the decision on membership to be made by the Native Hawaiian Governing Entity itself. ${ }^{240}$

Another concern was raised by Professor MacKenzie: she noted that this is an administrative rule enacted under the Obama administration and will not be tested until a Native Hawaiian entity seeks to go through the process. ${ }^{241}$ Moreover, because the rule was promulgated by the executive branch, a challenge would be more likely under the theory that that the rule "overreaches" since it is Congress that has plenary authority over Indian affairs. ${ }^{242}$

Though many are concerned about the implications of this rule, it is likely the most available and practical steppingstone to achieving a Native Hawaiian sovereign, and more pertinently, food sovereignty. Creating a Native Hawaiian governing entity under the federal regulation could provide a number of jurisdictional solutions for Hawaiians: land ownership rights, the power to regulate agriculture, and a right to produce and self-sustain off of culturallyappropriate food. ${ }^{243}$ And in fixing Native Hawaiian jurisdictional issues, Hawaiian health concerns would also be remedied.

Essentially, establishing a Native Hawaiian sovereign would allow for food sovereignty because Hawaiians would likely have more land rights and thus will have a right to producing culturally- and nutritionally adequate foods on their own terms. In other words, the land could be used to grow crops that support the Traditional Hawaiian Diet. And in having more access to THD foods, Hawaiians with chronic diseases in which dietary changes can have a positive impact (e.g. diabetes and hypertension) would benefit immensely.

This proposal can be applied to specific contexts as well, such as the A\&B land sale to Mahi Pono. If a Native Hawaiian governing entity is created, it is possible that those privately-owned sugarcane lands could transition into trust lands within Native Hawaiian power. A portion of those trust lands could then become agricultural land for Maui farmers to grow taro, breadfruit or purple yams. With a higher production of THD foods comes easier and cheaper access to said foods; this is food sovereignty. And food sovereignty can better supplement programs that work to combat Hawaiian health issues, such as the Simply Health Café of Hui No Ke Ola Pono.

\section{Conclusion}

Attaining food sovereignty for the benefit of Hawaiian health begins with restoring Hawaiian land rights, and reclaiming land rights begins with more

the State of Hawaii."

240. Id. at 71314. Many of the responses to the "two types of Hawaiians" criticisms reflect the ideal that until the Native Hawaiian government comes into existence, the baseline criteria will reflect the Native Hawaiian community and programs that Congress has already acknowledged.

241. Interview, supra note 23.

242. See id.

243. See Bell-SheEter, supra note 11, at 4. 
political power. Seemingly, building a Native Hawaiian government first, with the hopes of eventual independence, is the most accessible way to do so. ${ }^{244} \mathrm{Most}$ Hawaiian legal issues are dismissed because we have no political power ${ }^{245}$ And yet, there is pushback to the idea of federal recognition for fear of giving up claims of independence. ${ }^{246}$ However, this proposal does not wish to give up a claim to independence either; rather, it urges Native Hawaiians to consider looking past our intra-community opinions to work toward one goal: eventual independence. It is easy to dwell on the past wrongs experienced by Hawaiians the overthrow of our monarchy, the negative health impacts of a Westernized diet, and the setbacks of transitioning to a Western land ownership system.

The "wrongs" continuously discussed by Hawaiian activists are common to all indigenous communities, including those of Indiana. Similar to what happened with Native Hawaiians, in the late 18th century, the Native Americans of Indiana came to the realization that the British and American colonists' main goal was to take Native American land. ${ }^{247}$ The Native Americans were unfamiliar with the British-American concept of land tenure and fought endlessly with the Americans; by 1794, a treaty was drafted and signed, stating that the Native Americans gave up a strip of land in southeastern Indiana in exchange for goods worth $\$ 20,000$ and an annual payment to all the tribes, ranging from $\$ 500$ $\$ 1000 .^{248}$ The Native American leader who signed the treaty, Chief Little Turtle, had the same spirit as Queen Lili'uokalani in that he hoped signing the treaty would improve the conditions for his people, even though it meant that the Americans now had sole authority. ${ }^{249}$

Chief Little Turtle and Queen Lili' uokalani did what was best for their people at the time, and the Native Hawaiian community faces a choice to do what is best for our people now. In order to move forward in reclaiming our identity, health, and land rights, Native Hawaiians must work with what is available to us: 43 C.F.R. $\S 50$. Native Hawaiians need access to their own land because it touches all aspects of our health - physically, spiritually, mentally, and emotionally. ${ }^{250}$ While private entities, such as A\&B and Mahi Pono, promise to keep the agricultural integrity of our land and consider the incorporation of traditional

244. Interview, supra note 23.

245. See section V, subsection A for examples.

246. See section V, subsection B for theories of Hawaiian rights advocacy; Anaya \& Williams, supra note 24.

247. James H. Madison \& Lee Ann Sandweiss, Hoosiers and the American Story, 8 (2014), https://indianahistory.org/wp-content/uploads/Hoosiers-and-the-American-Story-FullText.pdf [https://perma.cc/D3HX-FXBF].

248. Id. at 11-12.

249. Id. at 12.

250. Interview, supra note 23. 
Hawaiian foods into their plans, the reality is that these promises are subject to many variables. ${ }^{251}$ In other words, this is not food sovereignty. However, with the establishment of a Native Hawaiian governing entity, the possibility of food sovereignty and a healthier Native Hawaiian community becomes much more possible because with land, comes power. ${ }^{252}$

251. See generally Uechi, supra note 152; Projects, supra note 149.

252. See generally Procedures for Reestablishing a Formal Government to Government Relationship with the Native Hawaiian Community, 81 Fed. Reg. 71278. 